\title{
Relationship between Self-Regulated Learning and Muraqabah with Academic Dishonesty of Muslim Graduate Students
}

\author{
Rizky Susanty ${ }^{1}$, Lydia Freyani Hawadi ${ }^{2}$ \\ rizky.islamicpsy@gmail.com \\ Sekolah Kajian Stratejik dan Global, Universitas Indonesia
}

\begin{abstract}
Academic dishonesty has become a major problem in education to date. This study examines the academic dishonesty on Muslim graduate students. There are two kinds of factors encouraging graduate students to cheat: 1) the factors that can be controlled by students, such as lack of preparation before exams, fatigue, or lack of time to learn; 2) the factors that are beyond the students' control, such as health problems, tasks or exams that are too difficult, or friends' cheating. In self-regulated learning, students manage their learning effectively. Thus, these controllable factors of academic dishonesty are expected to be overcame by student's improving self-regulated learning. Meanwhile, muraqabah, defined as awareness of God's supervision, is predicted to help students in overcoming the uncontrollable factors of academic dishonesty. This study uses quantitative approach. The participants were Muslim graduate students. Four instruments were used in this study: self-regulated learning questionnaire, muraqabah questionnaire, academic dishonesty questionnaire, and social desirability scale. The data was analyzed using descriptive statistics and partial correlation analysis technique. The result of this study determines that there is a significant negative correlation between self-regulated learning and academic dishonesty of Muslim graduate students. There is no significant correlation between muraqabah and academic dishonesty.
\end{abstract}

Keywords : Academic dishonesty, graduate students, self-regulated learning, muraqabah, Islamic psychology

\section{INTRODUCTION}

In the world of education, academic dishonesty has long been a problem in various countries. The Center of Academic Integrity (CAI) collected data from 50,000 undergraduate students from 60 campuses and found that $70 \%$ of students had cheated, $25 \%$ cheated on a serious level on examinations, and $50 \%$ on written assignments [1]. In Indonesia, a similar survey was conducted in 2007 by the Litbang Media Group Survey of 480 adult respondents in six major cities, namely Makassar, Surabaya, Yogyakarta, Bandung, Jakarta, and Medan. The results show that $70 \%$ of them have cheated when they were in school or college [2].

On the other hand, what is increasingly concerning, is when academic dishonesty is carried out by people who have reached a high level in education. In fact, some of them were exposed when the culprit had held an important position in college. For example, the case that happened lately, namely the disclosure of plagiarism in a dissertation owned by the chancellor of one of the famous universities in Jakarta (BBC.com, 2) [3].

Wajda-Johnston, Handal, Brawer, and Fabricatore [4] conducted research on academic dishonesty by involving 246 graduate students (master and doctoral) from various disciplines. 
When given the question "Have you ever cheated during your graduate studies?", As many as 69 participants $(28 \%)$ claimed to have done so. However, when given a scale containing forty specific behaviors related to academic dishonesty, different results were obtained. At each of these behaviors, the number of participants who claimed to have done it ranged from $2.5 \%$ to $55.1 \%$ of all participants.

Minarcik and Bridges [1] conducted a study of 366 participants who were graduate students majoring in Psychology. The results showed that there were 16 people who reported that they had committed academic dishonesty while undergoing graduate programs. This academic dishonesty is divided into three levels. The first level included $56 \%$ of participants who used the source without the author's permission (cheating) for the test or assignment, 13\% of participants who falsified the source of the quote, and one participant who re-collected their thesis as a new work. The second level includes the act of plagiarism of information from the internet and makes it part of the writing itself, does not include sources, and collects the writings of other people who have been published, changed them a little, and collected them as personal tasks. After further interviews, $31 \%$ of the sixteen participants felt guilty for the action. However, $44 \%$ of participants intend to repeat it on another occasion.

In a study conducted by Brown [5], it was found that Business graduate students have academic cheating rates that are similar to undergraduate students known from previous studies. So far, research on academic dishonesty on graduate students is still very little.

Several previous studies revealed a number of reasons that led to academic dishonesty behavior in graduate students, including lack of preparation, tasks that were too difficult, experiencing unexpected pressure (eg health problems), having the ability and opportunity to cheat, wanting success, experiencing fatigue, or knowing there were other students cheating. There are also those who cheat because they lack the time to study, have time but do not study, assume that academic dishonesty behavior does not harm anyone, and the risk is small to be discovered [1] [5]. These reasons can actually be classified into two types, namely the factors that can be controlled and the factors that cannot be controlled by students.

The researchers presumed the controllable factors can be overcome by implementing selfregulated learning. According to Pintrich [6], self- regulated learning is a process in which learners actively set goals for their learning. Then they monitor, regulate, and control their cognition, motivation and behavior. This process is guided and limited by the goals set by the learners and the contextual features of the environment around them.

McCallister and Watkins [7] analyzed academic dishonesty that occurs in online classes based on various previous studies and combined with their experience. According to McCallister and

Watkins [7], the intensity of cheating and plagiarism can be reduced by developing selfregulated learning skills of online class participants. With these skills, they will have a better understanding of the goals expected of online classes. In addition, they will worry less about their success without cheating. McCallister and Watkins [7] suggested further research on these matters. Therefore, self-regulated learning was chosen in this study as an independent variable whose correlation would be tested with academic dishonesty of graduate students.

On the other hand, regarding the uncontrollable factors of academic dishonesty, researchers presumed that students' religiosity can overcome them. Religious values teach people to distinguish between right and wrong. The extent to which an individual's level of obedience to beliefs, doctrines, and practices of religion is referred to as religiosity [8].

Several previous studies have been conducted to determine the role of religiosity in influencing learners' decisions to conduct academic dishonesty. In the study of Bloodgood, 
Turnley, and Mudrack [9], it was shown that learners who attended worship more often, as an indicator of religiosity, proved to be less cheating than those who rarely attended worship. Storch and Storch [10] also found a negative correlation between non- organizational religiosity and intrinsic religiosity with academic dishonesty. Non-organizational religiosity is defined as the amount of time a person spends doing personal worship practices, such as praying. Intrinsic religiosity is how well one integrates their religious beliefs into life.

Nelson, James, Miles, Morrell, and Sledge [11] found that religiosity predicts a decline in cheating behavior carried out by millennial generation students. In addition, religiosity also predicts student attitudes towards academic dishonesty. Those with high religiosity tend to have a negative attitude towards cheating behavior. Meanwhile, in Indonesia, Jena and Sihotang [12] found a number of students who had never committed academic dishonesty for several reasons, including fear of sinning and wanting to commit to religious beliefs. These studies prove that adherence to religious values or religiosity can hinder learners from doing academic dishonesty.

However, there are also different findings. Jurdi, Hage, and Chow [13] examined a number of variables suspected of academic dishonesty factors in student samples in Canada. One of them is the level of religious feeling. The results show no correlation between religious feeling and academic dishonesty.

Hadjar [14] examines the relationship between religiosity, which consists of religious beliefs and religious behavior, with academic cheating on students in Indonesia. From the study it was found that both religious beliefs and religious behavior had no influence on academic dishonesty. That is, in these two studies, the level of religiosity one cannot help in preventing academic dishonesty.

These findings indicate that empirical evidence regarding the effect of religiosity to academic dishonesty has not been consistent. Someone with high religiosity will not always avoid cheating. In fact, the teachings of any religion oppose the form of dishonesty. The inconsistencies that occur in the results of the study can be caused of religiosity is a large construct. There are various parts that build a person's religiosity.

So, the question is which part of the teachings of religion plays the most central role in preventing someone from acting dishonestly? Different from general moral studies, the implementation of religious teachings is believed to be a form of obedience to God. Religious believers believe that their submission to religious values is an order from Almighty God. In fact, believers believe in the consequences they will receive if they violate religious values. In Islam, there is the threat of torment of hell for those who sin, which is to do acts that are prohibited by religion. Muslims also believe that their behavior is always under God's supervision. In the Qur'an, Allah SWT's supervision of humans is explained in a number of His words,including:

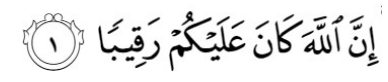

"... Surely Allah always safeguards and watches over you." (Surah An-Nisa, 4: 1).

This passage of the verse explains that God Almighty always oversees humanity. Not only acts, but also a whisper in the heart. In another verse, Allah SWT says,

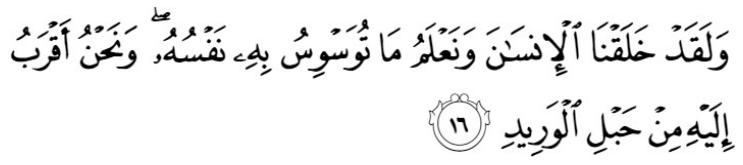


"And verily We created man and know what his heart has whispered, and We are nearer to him than his veins." (Surah Qaf, 50:16).

In the Tafsir Ibn Katsir, the verse intends to explain that the knowledge of Allah SWT covers all affairs until Allah SWT knows that whispered by the human heart, both good and bad. Meanwhile, the fragmentation of "We are closer to him than his veins" is interpreted as the angels of Allah SWT which is closer to man than his veins. In the next paragraph, Surah Qaf, 50: 17 mentions that two angels assigned to record human deeds. These verses are part of the Qur'an verse that convey to man that they are always under the control of Allah SWT, from deeds to the heart. Thus, according to Muslim beliefs, humans cannot hide anything from Allah SWT.

In Islam, this belief is known as muraqabah. Al- Qusyairy [15] states that people who are consistent with muraqabah are those who always watch over themselves because they feel they are always watched by Allah SWT. Thus, they always keep themselves in accordance with the laws of Allah SWT. Imam Ghazali [16] mentions the existence of three types of muraqabah. One of them is muraqabah in avoiding immorality. Academic dishonesty is included because it is a form of dishonesty that is opposed by Islamic teachings. With high muraqabah, students should consider many times before deciding to engage in academic dishonesty, especially if they are Muslims. So, muraqabah is chosen as the second independent variable. The combination of self-regulated learning and belief in God's supervision of Muslim graduate students has the potential to address these academic dishonesty problems optimally.

Based on the introduction above, the hypothesis of this study are:

1. Self-regulated learning will be negatively correlated with academic dishonesty of Muslim graduate students.

2. Muraqabah will be negatively correlated with academic dishonesty of Muslim graduate students

\section{LITERATUR REVIEW}

\subsection{Academic Dishonesty}

The University of Sydney, on its official website [17] defines academic dishonesty as a dishonest act carried out by students to gain academic benefits, including helping others to carry out these actions. Northern Illinois University, on its website regarding the academic integrity tutorial (https://www.niu.edu/academic-integrity) [18], mentions academic dishonesty as a dishonest act regarding academic activities in the academic environment whether intentional or not. According to the university, there are two main keys in identifying academic dishonesty, namely practices that are not permitted and undue use of the work of others to do academic assignments.

In this study, the academic dishonesty of graduate students studied consisted of five types. They are:

1. Bribery or negative persuasion to lecturers, defined by trying to get academic benefits by doing unjustified persuasion to lecturers, bribing, threatening, or utilizing kinship relationships. It is exemplified by the behavior of giving gifts to lecturers to get good grades.

2. Plagiarism, divided into two types, namely plagiarism of self-owned works (selfplagiarism) and plagiarism of the work of others.

3. Falsification, defined by making up or changing a document, data, or information to get 
academic benefits. It is exemplified by falsifying course attendance list when actually not attending.

4. Cheating during exams, appears in the behavior of opening lecture notes and using smartphones to answer closed book exams.

5. Joint cheating, exemplified by cooperation that is not permitted, both in the execution of individual assignments and examinations.

\subsection{Self-Regulated Learning}

This concept is rooted in Albert Bandura's notion of self-regulation, namely the capacity of humans to regulate their own behavior through reactive and proactive strategies. Humans are believed to be reactive in reducing the gap between their achievements and the goals they want to achieve. After overcoming these gaps, humans will proactively set new goals that are higher for themselves [19]. The application of self-regulation in an academic context is known as self-regulated learning.

Pintrich [6] states that in self-regulated learning there are strategies that learners can apply in four areas, namely cognition, motivation/affection, behavior, and context. Regulations in the area of cognition include activities, tactics, and strategies used by learners in planning, monitoring, and regulating their cognition. There are six strategies in the area of cognition measured in this study:

1. Planning, includes specific goal setting in learning, task analysis, activation of prior knowledge (prior knowledge) relevant to facilitate the regulation and understanding of the material to be studied, and activation of learners' metacognitive knowledge of the task or themselves.

2. Monitoring, that is awareness of the development of learning towards the goals and monitoring of the understanding that has been obtained (for example by paying attention to yourself when reading and testing yourself through question and answer) in order to be able to carry out various adaptations needed in learning.

3. Regulation of cognition, which is continuous adjustment of cognitive activity is done by examining and correcting behavior when doing a task.

4. Rehearsal, done by repeatedly mentioning the material learned to activate information stored in short-term memory (working memory).

5. Elaboration, includes strategies that help learners to store information in long-term memory (long-term memory) by building internal connections between the material being studied, including paraphrasing, summarizing, making analogies, and writing notes.

6. Organization, includes strategies that help learners to choose information and build connections between information learned, for example by grouping, sketching, and finding key ideas in reading.

Regulations in the area of motivation/affection involve a number of motivational concepts. In this study, the measured motivation was:

1. Intrinsic goal orientation, defined by the extent to which learners participate in learning due to reasons such as challenges, curiosity, and the desire to master the material being studied.

2. Task value, which is the learners' perception of how interesting, important, and useful a task or material is learned.

3. Control of learning beliefs, which is the learners' belief that their efforts will produce 
positive results and not depend on external factors so that they feel they have control over their academic performance.

4. Self-efficacy, which is the learners' belief of his ability to master the material learned and his confidence in his skills in completing tasks.

Regulations in the area of behavior and context involve four strategies called Pintrich et al. [20] as empowering resource management strategies. This study measured three strategies in area of behavior, they are:

1. Time study management, includes scheduling, planning, and managing study time and effective use of time and realistic goal setting.

2. Effort regulation, which is controlling and maintaining effort and attention as a form of commitment to the learning goals even when faced with disturbances and difficulties.

3. Help seeking, includes learners identifying people in their environment who can provide assistance when they experience difficulties in learning, for example through peer tutoring or teachers who can individually facilitate learning.

and two strategies in area of context, they are:

1. Environment study management, which is an arrangement at a learning location that is ideally neat, calm, and free from visual and auditory disturbances.

2. Peer learning, includes collaborating and discussing with peers to clarify the material and get an understanding that might not yet be owned

Furthermore, there are some supportive strategies that also measured in this study, they are:

1. Critical thinking, the extent to which the learner applies prior knowledge to new situations to solve problems, make decisions, or make critical evaluations.

2. Extrinsic goal orientation, the extent to which learners participate in learning due to reasons such as grades, rewards, achievements, evaluations from others, and competitions.

3. Regulation of test anxiety that includes worries, namely negative thoughts that interfere with performance, as well as emotional and physiological reactions

\subsection{Muraqabah}

According to Imam Ghazali [16], muraqabah is a concern, guarding, or self-supervision to always direct the heart to Allah SWT who always supervises and looks after humans. Ibn Qayyim al-Jauziyah [21] interpreted muraqabah as a servant's knowledge continuously and his belief that Allah SWT knows zahir (outward side) and his mind. Muraqabah appears in three types of human actions, namely:

1. Muraqabah in carrying out obedience, means doing good deeds with sincerity or pure intention, keeping it from mistakes and defects, and perfecting it by doing the best.

2. Muraqabah in avoiding evil deeds or immorality, means regretting and repenting immorality.

3. Muraqabah in safeguarding halal deeds, means maintaining and maintaining adab on things that are moral, adhering to the rules, and being grateful when obtaining favors from Allah, the Most Merciful [16].

Sufism expert and lecturer at the Faculty of Social Sciences, Universitas Negeri Jakarta (UNJ), Dr. Andy Hadiyanto, M.A mentions that muraqabah has several levels in muraqabah that are related to the testimony of a servant to the divinity of Allah SWT as "He", "Thou", and 
"I". Here is the explanation:

1. Low level muraqabah (Laa ilaaha illa Huwa/there's no God but Him) With low level muraqabah, one is aware of the supervision of Allah SWT as the Giver of reward or punishment for human actions. They will be encouraged by someone to do deeds that are outward in nature by focusing on the consequences received.

2. Medium-level muraqabah (Laa ilaaha illa Anta/there's no God but You)

With medium-level muraqabah, one realizes the supervision of Allah SWT as the God who is expected to be His pleasure. Muraqabah at this level encourages a person to practice deeds of qalbiyah (heart) and practice deeds of aqliyah (mind). The aim is to gain the pleasure of Allah SWT.

3. High-level of muraqabah (Laa ilaaha illa Ana/there's no God but I)

With high level muraqabah, God's values have been internalized into a person so that he is compelled to behave in line with those values. This high muraqabah is manifested in ruhiyah practices. Those who are at the high level of muraqabah will do good deeds and leave disobedience because they want to be a good person and emit the light of Allah SWT through him. They also no longer focus on personal gain but their usefulness for life. Allah SWT has been very close to them with high muraqabah because His values are internalized into themselves and become part of one's character.

\section{METHODS}

This study used a quantitative approach and involved 194 Muslim graduate student respondents (age between 22-55 years) from various universities, including public and Islamic colleges. Among them 76.8\% were studying for Master Program (S2), 2.1\% education for specialist doctors, $7.7 \%$ for Master graduates, and 13.4\% for Doctoral Program (S3) education with varied fields of science.

The selection of respondents used convenience sampling techniques, defined by choosing respondents based on what the researcher could reach. Respondents' criteria are: 1) graduate student; 2)Muslim.

The variables studied consisted of two independent variables, namely self-regulated learning and muraqabah, and one dependent variable, namely academic dishonesty in graduate students. These variables were measured using three instruments:

1. Self-Regulated Learning Questionnaire

It consists of 40 statements measuring regulation strategies in four areas, which are cognition, motivation/affection, behavior, and context, and also the supportive strategies, such as critical thinking. Each statement is followed by five responses, ranging from "very unlikely" to "very likely". This questionnaire has a validity coefficient of 0.893 and a reliability coefficient of 0.96 .

2. Muraqabah Questionnaire

It consists of 20 questions measuring the levels of muraqabah. Every question is followed by a set of multiple choice. There are four responses that can be selected by respondents. Each response represents a level of muraqabah. The validity and reliability of this questionnaire was assessed qualitatively through expert judgments. 
3. Graduate Student Academic Dishonesty Questionnaire

It consists of four scenarios that represent five kinds of academic dishonesty behavior. Each scenario is followed by some statements measuring the perception toward and the frequency of the academic dishonesty behaviors. This questionnaire has a validity coefficient of 0.961 and a reliability coefficient of 0.836 .

In addition, researchers also use the short version of adaptation of Social Desirability Scale [22] to detect the presence of social desirability bias in measuring academic dishonesty in respondents. Social desirability bias is the tendency of people to manipulate the impression of themselves so that they aren't look bad. This bias can disrupt the validity of the data obtained from respondents.

The four questionnaires were packaged in an online questionnaire with the help of Google Form which was then to be shared via the Whatsapp application to graduate students. The collected data was analyzed using descriptive statistical analysis techniques and partial correlation.

\section{RESULTS}

The following is the result of descriptive statistical analysis of research variables.

Table 1: Descriptive Statistical Analysis of Variables

\begin{tabular}{lccc}
\hline Statistics & $\begin{array}{c}\text { Self- } \\
\text { Regulated } \\
\text { Leaning }\end{array}$ & $\begin{array}{c}\text { Muraqab } \\
\boldsymbol{a h}\end{array}$ & $\begin{array}{r}\text { Academi } \\
\text { c Dishonesty }\end{array}$ \\
\hline $\begin{array}{l}\text { Minimum } \\
\text { score }\end{array}$ & 0 & 86 & 27 \\
Maximum & 38 & 172 & 79 \\
score & 38 & 86 & 52 \\
Range & 8.91 & 132.37 & 55.36 \\
Mean & 7 & 132,5 & 55 \\
Median & 0 & 129 & 56 \\
Mode & & 14.3 & 7.87 \\
Standard & 7.56 & & \\
deviation & & &
\end{tabular}

The results of the analysis above show that, in the self-regulated learning variable, respondents as a whole have a score range of 86 , that is, from a minimum score of 86 to maximum score of 172. The average self-regulated learning score is 132.37 , the middle score (median) is 132.5 , and the most appearing score (mode) is 129. Estimated average deviation of the respondent's score from the average score (standard deviation) of self-regulated learning is 14.3.

Then, in the muraqabah variable, the results of the analysis show that the respondents as a whole have a score range of 52, that is, from a minimum score of 27 to maximum score of 79. The average muraqabah score is 55.36, the middle score (median) is 55, and the most appearing score (mode) is 56. Estimated average deviation of the respondent's score from the average score (standard deviation) self- regulated learning is 7.87 .

Meanwhile, on the academic dishonesty variable of graduate students, the respondents as a whole had a score range of 38 , that is, from a minimum score of 0 to maximum score of 38 . 
The average academic dishonesty score of graduate students is 8.91, the middle score (median) is 7 , and the score that appears the most (mode) is 0 . Estimated average deviation of the score from the average score (standard deviation) self-regulated learning is 7.56.

Then, before conducting a correlation analysis between variables, the researchers tested the correlation between academic dishonesty in graduate students with social desirability. The results show a significant negative correlation $(r=-0,161, p=0,025)$ between the two. Thus, in the correlation test between variables, social data desirability is controlled. The following are the results of partial correlation analysis.

Table 2: Partial Correlation Analysis Result

\begin{tabular}{|c|c|c|c|}
\hline Variable & $\begin{array}{r}\text { Self- } \\
\text { regulated } \\
\text { learning }\end{array}$ & $\begin{array}{l}\text { Muraqab } \\
\text { ah }\end{array}$ & $\begin{array}{l}\text { Academic } \\
\text { dishonesty on } \\
\text { graduate } \\
\text { students }\end{array}$ \\
\hline $\begin{array}{l}\text { Self- } \\
\text { regulated learning }\end{array}$ & - & $\begin{array}{r}0,77 \\
(\mathrm{p}= \\
0,143)\end{array}$ & $0,03)^{-0,135^{*}}(\mathrm{p}=$ \\
\hline Muraqabah & & - & $\begin{array}{c}-0,077 \\
(p=0,145)\end{array}$ \\
\hline $\begin{array}{l}\text { Academic } \\
\text { dishonesty } \\
\text { graduate } \\
\text { students }\end{array}$ & & & - \\
\hline
\end{tabular}

Based on the table above, it appears that self- regulated learning significantly $(p=0.03)$ is negatively correlated $(\mathrm{r}=-0.135)$ with academic dishonesty in graduate students. That is, the higher the self-regulated learning score, the lower the academic dishonesty score. The better the respondent in implementing self-regulated learning, the lower the academic dishonesty behavior he did. Thus, the first hypothesis of this research is proven.

Meanwhile, muraqabah did not have a significant correlation $(\mathrm{p}=0.145)$ with academic dishonesty in graduate students. This means that the high or low muraqabah score is not related to the high or low academic dishonesty score. The muraqabah level in the respondents is not related to the academic dishonesty behavior that they do. Thus, the second hypothesis of this study was not proven.

\section{DISCUSSION}

This study reveals that academic cheating is still done by students who are already at the level of graduate study. Although in terms of age it is more mature, in reality graduate students can still choose to cheat in completing their academic tasks. Actually, academic cheating can also be considered a "strategy" for graduate students to succeed in the midst of the obstacles faced in lectures. The opposite of this illegal "strategy" are strategies in self-regulated learning that are planned and executed proactively by students to achieve their learning goals. The results of this study prove that graduate students with good self-regulated learning tend to do less academic dishonesty. This finding was marked by a significant negative correlation 
between the two. McCallister and Watkins [7] suspect that by formulating learning designs that involve self- regulated learning will reduce the potential for academic cheating online class participants. This study found evidence supporting this assumption. So, one of the efforts to suppress the emergence of academic dishonesty behavior is by increasing self- regulated learning in graduate students.

Meanwhile, muraqabah was found not to be related to the academic cheating of graduate students. This finding can be due to muraqabah being a concept in Sufism that is familiar to people who are deep in the knowledge. Meanwhile, the respondents of this study were students who were generally common people and not from tarekat participants. If analyzed by the level of muraqabah, most of them can be estimated to be at the low and middle levels. Muraqabah high level are Sufis.

However, the results of this study are in line with several previous studies which showed that one's religiosity does not affect the academic dishonesty they did [13]. More specifically, Mustapha, Hussin, Siraj, and Darussalam [23] examined the effect of Islamic religiosity on academic dishonesty tendencies in Muslim students in Malaysia. The results also show that the data obtained do not support their research hypothesis. Religiosity was found not to have a significant role in the tendency of Muslim student academic dishonesty.

This does not mean that religious values cannot prevent someone from committing academic dishonesty. In fact, cheating and plagiarism can be considered as something normal because it often happens. In this study, it appears that quite a number of respondents who disagree that the behaviors in the questionnaire they fill out are academic dishonesty.

When tested for correlation, it turns out that respondents' perceptions as a whole have a significant negative correlation $(-0.317)(\mathrm{p}=0)$ with academic dishonesty in graduate students. That is, the more respondents assume that the academic dishonesty in question is wrong, the less they do it. This can be a sign that perception is an important factor that determines academic dishonesty of graduate students. Muslims believe that all their actions in this world are related to their relationship with Allah SWT. The rules that Allah Almighty determines should be able to influence the way Muslims judge the correctness of wrong actions. What are the

perceptions of Muslim graduate students in assessing the correctness of wrong academic dishonesty? Do they believe cheating is a sin that will be held accountable in the hereafter? Do they think plagiarism is a behavior that violates religious values?

In Islamic teachings, indeed there are no verses or hadith that specifically mention the academic dishonesty law. However, this behavior can be classified as academic dishonesty. Prophet Muhammad SAW said,

"Whoever deceives us, then he does not belong to us." (Hadith Muslim).

For Muslims, this perception should not only be limited to whether academic dishonesty is a behavior that violates moral values. Muslims believe that all their actions in this world are related to their relationship with Allah SWT. The rules that Allah SWT establishes through Islamic teachings should affect Muslim ways of judging the true wrongness of an action. These include perceptions of academic dishonesty.

However, in reality, it is not certain that students take the academic dishonesty sin seriously. In fact, they might perceive that behavior is not an act of sin or, in line with secularism, they assume that academic cheating has nothing to do with religion.

This kind of student perception of academic dishonesty may be the third variable that influences the relationship between muraqabah and academic dishonesty. That is, muraqabah 
is possible to negatively correlate with academic dishonesty if Muslim graduate students have a perception that the behavior includes acts that violate religious values and are not in line with the rules of Allah SWT.

Thus, for further research, students' perception of academic dishonesty can be a research variable that influences the relationship between muraqabah and academic dishonesty. That is, muraqabah is possible to negatively correlate with academic dishonesty if Muslim graduate students have a perception that the behavior includes acts that violate religious values and are not in line with the rules of Allah SWT.

This study has a number of limitations. First, as already mentioned, the muraqabah variable under study is a psychological attribute that is more appropriate to be studied among people who study and practice Sufism, not on ordinary people. Second, even though researchers have tried their best in avoiding social desirability bias, this bias still appears in the academic dishonesty data of graduate students. Third, the selection of samples by convenience sampling technique makes the respondents' characteristics obtained less evenly in demographic variations. For example, based on the type of college, respondents who are students of public universities are far more than students of Islamic colleges. This imbalance can affect how representative the sample is in describing the population.

\section{SUGGESTION}

Here are suggestions for future research.

1. The researcher can choose Muslim perspective toward academic dishonesty as an independent variable that may be correlated with academic dishonesty behavior.

2. Researchers need to find a more precise way to avoid social desirability bias in the data of academic dishonesty.

\section{ACKNOWLEDGEMENT}

We would like to thank HIBAH PITTA (Publikasi Terindeks Internasional untuk Tugas Akhir) Universitas Indonesia which has provided financial support for this study.

\section{REFERENCES}

[1] Minarcik, J. \& Bridges, A.J. (2015). Psychology Graduate Students Weigh In: Qualitative Analysis of Academic Dishonesty and Suggestion Prevention Strategies. Journal Academic Ethics, 13, 197-216, Springer.

[2] Nursalam, Bani, S., \& Munirah. (2013). Bentuk Kecurangan Akademik Mahasiswa PGMI Fakultas Tarbiyah dan Keguruan UIN Alauddin Makassar. Lentera Pendidikan, 16, 2, 127138.

[3] Utama, A. (2017, 28, September). Rektor UNJ Dicopot Sementara, Gelar S3 Doktor Plagiat Sepatutnya Juga Dibatalkan. BBC Indonesia. Diakses dari http://www.bbc.com/indonesia/indonesia-41416802.

[4] Wajda-Johnston, V.A., Handal, P.J., Brawer, P.A., \& Fabricatore, A.N. (2001). Academic Dishonesty at the Graduate Level. Ethics \& Behavior, 11, 3, 287-305. Lawrence Erlbaum Associates, Inc.

[5] Brown, B.S. (1995). The Academic Ethics of Graduate Business Students: A Survey. Journal of Education for Business, 70, 3, 151-156. Routledge. 
[6] Pintrich, P.R. (2004). A Conceptual Framework for Assessing Motivation and SelfRegulated Learning in College Students. Educational Psychological Review, 16, 4, 385-497. Springer Science+Business Media, Inc.

[7] McAllister, C. \& Watkins, P. (2012). Increasing Academic Integrity in Online Classes by Fostering the Developmeny of Self-Regulated Learning Skills. The Clearing House: A Journal of Educational Strategies, Issues and Ideas, 85, 96-101, Taylor \& Francis Group, LLC.

[8] Mattis, J.S. \& Jagers, R.J., A Relational Framework for the Study of Religiosity and Spirituality in the Lives of African Americans, Journal of Community Psychology, 29, 5: 519539, John Wiley \& Sons, Inc.

[9] Bloodgood, J.M., Turnley, W.H., \& Mudrack, P. (2008). The Influence of Ethics Instruction, Religiosity, and Intelligence on Cheating Behavior. Journal of Business Ethics, 82, 557-571. Springer.

[10] Storch, E.A. \& Storch, J.B. (2001). Organizational, Nonorganizational, and Intrinsic Religiosity and Academic Dishonesty. Psychological Reports, 88, 2,548-552. SAGE Publication.

[11] Nelson, M.F., James, M.S.L., Milles, A., Morrell, D.L., \& Sledge, S. (2016). Academic Integrity of Millennials: The Impact of Religion and Spirituality. Ethics \& Behavior, 00, 1-16. Taylor \& Francis Group, LLC.

[12] Jena, Y. \& Sihotang, K. (2015). "Winning is Everything" as the Basis of Academic Misconduct Among Indonesian Students. Sociology Study, 5, 2, 157-162. David Publishing.

[13] Jurdi, R., Hage, H.S., \& Chow, H.P.H. (2011). Academic Dishonesty in the Canadian Classroom: Behaviours of a Sample of University Students. Canadian Journal of Higher Education, 41, 3, 1-35. CSSHE SCEES

[14] Hadjar, I. (2017). The Effect of Religiosity and Perception on Academic Cheating among Muslim Students in

Indonesia. Journal of Education and Human Development, 6, 2, 139-147. American Research Institute for Policy Development.

[15] Naisaburi-An, A.Q.A.K.H. Al-Qusyairi. (2007). Risalah Qusyairiyah: Sumber Kajian Ilmu Tasawuf. Diterjemahkan dari Ar-Risalah Al-Qusyairiyah. Pustaka Amani.

[16] Ghazali, Imam. (2016). Ihya Ulumuddin (4): Menghidupkan Ilmu-Ilmu Agama. Diterjemahkan dari Ihya Ulumuddin edisi Inggris oleh Purwanto. Bandung: Penerbit Marja.

[17]Academic Dishonesty and Plagiarism. Accessed from https://sydney.edu.au/students/academic- dishonesty.html

[18]Academic Integrity Tutorials. Accessed from

https://www.niu.edu/academic- integrity/students/types/index.shtml

[19] Feist, J. \& Feist, G.J. (2008). Theories of Personality (7th Edition). AS: McGraw Hill

[20] Pintrich, P.R., Smith, D.A.F, Garcia, T. \& McKeachie, W.J. (1991). A Manual for the Use of the Motivated Strategies for Learning Questionnaire. The Regents of The University of Michigan.

[21] Jauziyah, Al-, I.Q. (1998). Madarijus Salikin (Pendakian Menuju Allah): Penjabaran Konkrit "Iyyaka Na'budu wa Iyyaka Nasta'in". Diterjemahkan dari Madarijus Salikin Manazili Iyyaka Na'budu wa Iyyaka Nasta'in oleh Kathur Suhardi. Jakarta: Pustaka A1Kautsar.

[22] Widhiarso, W. (2011). Evaluasi Properti Psikometris Skala Kepatutan Sosial Adaptasi dari Marlowe-Crowne Social Desirability Scale. Insan, 13, 3, 138148.

[23] Mustapha, R., Hussin, Z., Siraj, S., Darussalam, G. (2016). Does Islamic Religiosity Influence the Cheating Intention among Malaysian Muslim Students? A Modified Theory of Planned Behavior. International Journal of Academic Research in Business and Social 
Sciences, 6, 12, 389-406. HRMARS. 